\title{
ASOSIASI DAN RELUNG MIKROHABITAT GASTROPODA PADA EKOSISTEM MANGROVE DI PULAU SIBU KECAMATAN OBA UTARA KOTA TIDORE KEPULAUAN PROVINSI MALUKU UTARA
}

\author{
Salim Abubakar ${ }^{1}$, Masykhur Abdul Kadir ${ }^{1}$, Nebuchadnezzar Akbar ${ }^{2}$, \\ Irmalita Tahir ${ }^{2}$ \\ ${ }^{1}$ Program Manajamen Sumberdaya Perairan, FPIK. Universitas Khairun \\ Ternate \\ ${ }^{2}$ Program Studi IImu Kelautan, FPIK. Universitas Khairun Ternate \\ E-mail : salimbbkr@gmail.com
}

Received March 2018, Accepted April 2018

\begin{abstract}
ABSTRAK
Tujuan penelitian adalah untuk menganalisis asosiasi dan relung mikrohabitat gastropoda pada ekosistem hutan mangrove di Pulau Sibu Kecamatan Oba Utara Kota Tidore Kepulauan Provinsi Maluku Utara. Pengambilan sampel dilakukan pada saat air surut dengan menggunakan metode line transect. Hasil penelitian diperoleh komposisi jenis-jenis gastropoda di Pulau Donrotu sebanyak 12 jenis yaitu Littrorina scabra, Littorina undulata, Turbo agryrostoma, Turbo chrysostoma, Turbo breneus, Nerita costata, Nerita planospira, Strombus luhuanus, Cerithiidea cingulata, Telescopium telescopium, Telebralia sulcata dan Terebralia palustris. Pasangan jenis gastropoda yang diperoleh memiliki tipe asosiasi positif sebanyak 14 pasangan, asosiasi negatif sebanyak 11 pasangan dan tidak ada asosiasi sebanyak 42 pasangan. Jenis gastropoda yang mempunyai relung habitat terlebar adalah Terebralia sulcata dan tersempit adalah Turbo chrysostomus.
\end{abstract}

Kata Kunci : Asosiasi, relung mikrohabitat, gastropoda

\begin{abstract}
The objective of the present study was to examine niche and association Gastropoda microhabitat of mangroves ecosystem in Sibu Island. The sample collected when low tide by using line transects quadrant method. The result showed 12 spesies in gastropoda composition; Littrorina scabra, Littorina undulata, Turbo agryrostoma, Turbo chrysostoma, Turbo breneus, Nerita costata, Nerita planospira, Strombus Iuhuanus, Cerithiidea cingulata, Telescopium telescopium, Telebralia sulcata dan Terebralia palustris. The positive type of Gastropods association was found 14 pairs between gastropoda, negative type association was found 11 pairs between gastropoda and unassociation was found 42 pairs between
\end{abstract}


gastropoda. The species of gastropoda that has high niche habitat was Terebralia sulcata and low niche habitat was Turbo chrysostomus.

Keywords : Association, microhabitat niche, gastropoda

\section{PENDAHULUAN}

Ekosistem mangrove merupakan suatu ekosistem peralihan antara darat dan laut. Tumbuhan ini mampu tumbuh dan berkembang pada daerah pasang surut sesuai dengan toleransinya terhadap salinitas, lama penggenangan, subsstrat dan morfologi pantainya (Idris, 2004). Ekosistem hutan mangrove dengan sifatnya yang khas dan kompleks merupakan habitat bagi berbagai jenis hewan dari yang paling sederhana tingkatnya (Protozoa) sampai ke yang paling tinggi (Vertebrata). Sebagai daerah peralihan antara laut dan darat, ekosistem mangrove mempunyai gradien sifat lingkungan yang tajam. Pasang surut air laut menyebabkan terjadinya perubahan beberapa faktor lingkungan yang besar, terutama suhu dan salinitas. Karena hanya jenis-jenis fauna yang memiliki toleransi yang besar terhadap perubahan ekstrim faktor-faktor fisik itu dapat bertahan dan berkembang di hutan mangrove.Di dalam hutan mangrove, dikenal ada dua kelompok hewan yang dominan baik dalam keanekaragaman jenisnya maupun jumlah individunya, yaitu moluska dan krustasea (Saru, 2013).

Komunitas fauna hutan mangrove terdiri dari percampuran antara dua kelompok yaitu kelompok fauna daratan/teresterial dan kelompok fauna perairan/akuatik (Bengen, 2003). Kelompok hewan laut yang dominan dalam hutan mangrove adalah moluska, beberapa jenis ikan yang khas dan kepiting. Moluska diwakili oleh sejumlah siput, suatu kelompok yang umumnya hidup pada akar dan batang pohon bakau (Littorinidae) dan lainnya pada lumpur di dasar akar mencakup sejumlah pemakan detritus (Ellobiidae dan Potamididae). Kelompok kedua dari moluska termasuk bivalva, yang dominan dari bivalva adalah tiram. Mereka melekat pada akar-akar bakau (Nybakken, 1988). Relung ekologi merupakan posisi tertentu suatu spesies dalam suatu komunitas dan habitat yang ditempatinya sebagai hasil adaptasi struktural yang dicapainya lewat penyesuaian fisiologid dan pola tingkah lau khusus dalam memanfaatkan secara baik potensinya. Jadi relung ekologis adalah suatu kombinasi tertentu dari fator fisik (mikrohabitat) dan hubungan biotik (peranan) yang dibutuhkan oleh suatu spesies untuk aktifitas kehidupannya dan kelangsungan eksistensinya dalam suatu komunitas (Kendeight, 1980 dalam Rondo, 2001).

Berdasarkan penyebaran vertikal, fauna hutan mangrove memperlihatkan adanya relung ekologi berupa relung mikrohabitat setiap spesies, contohnya Littorina scabra adalah dominan di habitat mangrove yang menghadap laut terbuka, sedangkan Terebralia sulcata lebih menyukai daerah pedalaman hutan mangrove yang lebih dekat ke arah darat. Telescopium telescopium lebih menyukai habitat-habitat yang 
termasuk seperti genangan air yang luas (Saru, 2013). Asosiasi interspesifik merupakan ukuran kemampuan bergabung atau keeratan antara spesies. Asosiasi diukur dengan seberapa sering dua spesies terdapat dalam alokasi (sumberdaya) yang sama (Rondo, 2015). Lebih lanjut dikatakan Abubakar dan Ahmad (2013) bahwa jenis gastropoda yang hidup dalam eksositem mangrove ada yang saling berasosiasi atau membutuhkan sumberdaya yang sama seperti Telescopium telescopium dengan Terebralia sulcata, menempati substar berlumpur pada zona tengah dan belakang, jenis Monodonta labio dengan Littorina scabra menempati akar mangrove.

\section{MATERI DAN METODE}

\section{Tempat dan Waktu Penelitian}

Penelitian ini dilaksanakan pada ekosistem hutan mangrove di Pulau Sibu Kecamatan Oba Utara Kota Tidore Kepulauan. Waktu pelaksanaan penelitian selama 5 bulan yaitu Juli-Nopember 2017.

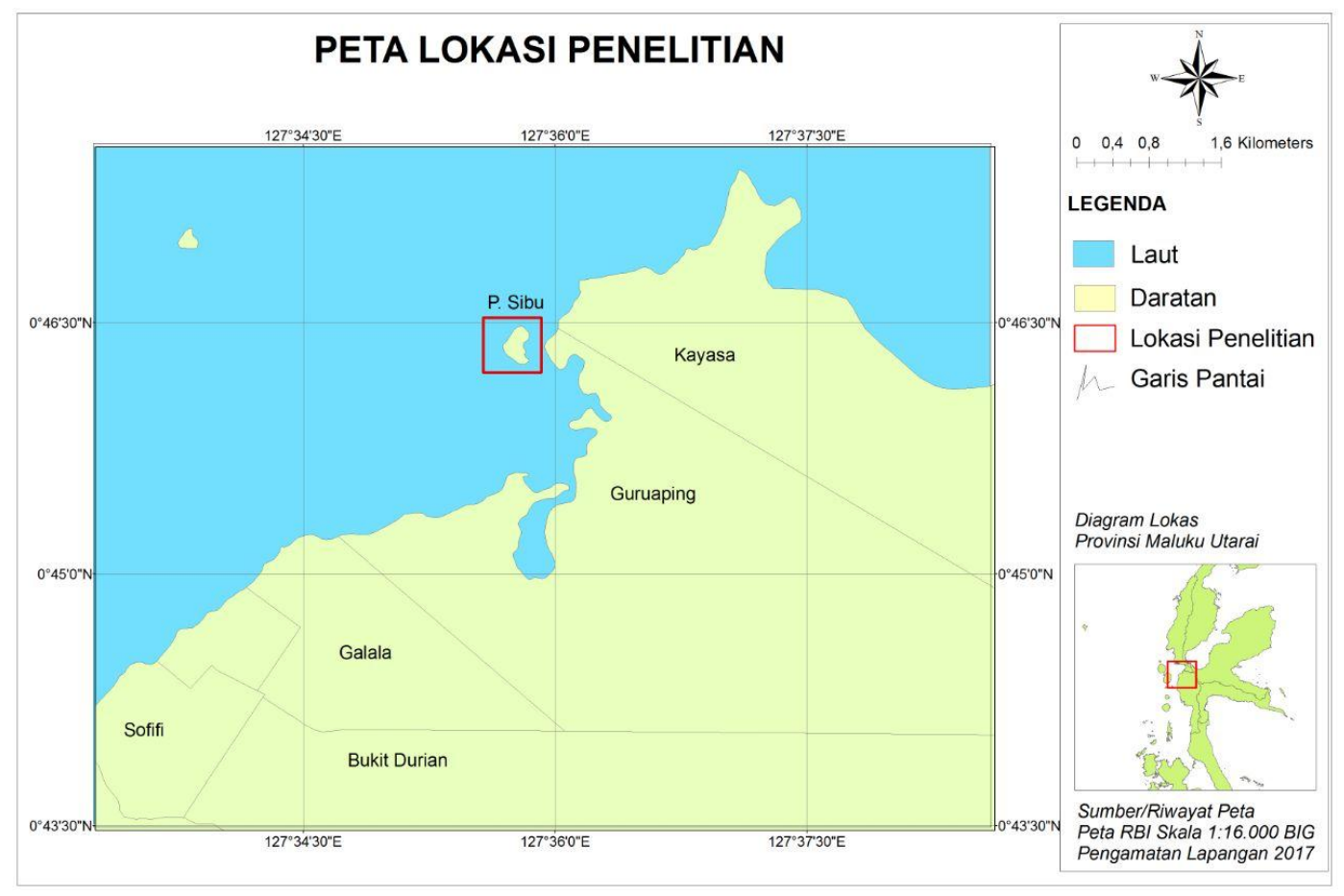

Gambar 1. Lokasi Penelitian

\section{Metode Pengambilan Data}

\section{Teknik Pengumpulan Data}

Teknik pengumpulan data dilakukan pada saat air surut dengan menggunakan metode Line transect kuadran, yang dibagi dalam tiga zona 
intertidal yaitu zona intertidal bagian depan (ZIBD), zona intertidal bagian tengah (ZIBT) dan zona intertidal bagian belakang (ZIBB)

\section{Prosedur Penelitian}

Prosedur penelitian diawali dengan menarik lintasan berdasarkan zonasi yaitu zona intertidal bagian depan (ZIBD), zona intertidal bagian tengah (ZIBT) dan zona intertidal bagian belakang (ZIBB). Pada setiap titik penarikan contoh itu dipasang tali secara horizontal yaitu sejajar dengan garis pantai. Kemudian pada setiap titik penarikan contoh, lima kuadrat yang berukuran $5 \mathrm{~m} \times 5 \mathrm{~m}$ diletakkan secara horizontal, dengan jarak antara kuadrat 20 meter.

Pengambilan sampel gastropoda dilakukan pada substrat, akar, batang, ranting dan daun mangrove atau dibatasi pada ketinggian 0-2,5 meter, dengan memperhatikan mikrohabitat dari masing-masing jenis gastropoda yang ditemukan. Gastropoda yang dikumpulkan kemudian dimasukkan ke dalam kantong plastik/wadah yang sudah diberi label, dan diawetkan dengan larutan formalin $10 \%$ atau alkohon $70 \%$, selanjutnya di bawah ke Laboratorium Fakultas Perikanan dan IImu Kelautan untuk diidentifikasi, dihitung jumlah individu setiap spesies gastropoda.

\section{Teknik Analisa Data} analisis:

Untuk mengukur struktur komunitas gastropoda, digunakan

\section{Asosiasi antar spesies gastropoda (Rondo, 2015)}

Tahapan analisis uji statistik dan kecenderungan asosiasi dua spesies yaitu:

1. Penyusunan pasangan spesies dengan bantuan tabel kontingensi $2 \times 2$ (Tabel 1):

Tabel 1. Kontingensi $2 \times 2$

\begin{tabular}{llll}
\hline Spesies A & Spesies B & \multicolumn{2}{c}{ Jumlah } \\
\cline { 2 - 3 } & Ada & Tidak ada & \\
Ada & a & B & $\mathrm{a}+\mathrm{b}$ \\
Tidak ada & $\mathrm{C}$ & $\mathrm{D}$ & $\mathrm{C}+\mathrm{d}$ \\
\hline Jumlah & $\mathrm{a}+\mathrm{C}$ & $\mathrm{b}+\mathrm{d}$ & $\mathrm{N}$ \\
\hline
\end{tabular}


Keterangan :

$a=$ Jumlah kuadran yang terdapat kedua spesies.

$b=$ Jumlah kuadran yang terdapat spesies $A$, tetapi spesies $B$ tidak.

$\mathrm{C}=$ Jumlah kuadran yang terdapat spesies $\mathrm{B}$, tetapi spesies $\mathrm{A}$ tidak.

$\mathrm{d}=$ Jumlah kuadran yang kedua spesies tidak terdapat.

$\mathrm{N}=$ Jumlah total kuadran.

2. Menyusun hipotesis

$\mathrm{H}_{0}=$ Kedua spesies tidak berasosiasi

$\mathrm{H}_{1}=$ Kedua spesies saling berasosiasi

3. Analisis statistik :

$$
\chi_{\text {hit. }}^{2}=\frac{N(a d-b c)^{2}}{[(a+b)(c+d)(a+c)(b+d)]}
$$

Dengan derajat bebas $(r-1)(c-1)$ atau (baris -1$)($ kolom -1$)=(2-1)(2-$ 1) $=1$ dan tingkat kepercayaan $5 \%$.

Kaidah pengambilan keputusan :

Jika $\chi^{2}{ }_{\text {hit. }}\left\langle\chi^{2}{ }_{(\alpha ; d b=1)}\right.$ terima $\mathrm{H}_{0}$

Jika $\chi^{2}{ }_{\text {hit. }}>\chi_{(\alpha ; d b=1)}^{2}$ tolak $\mathrm{H}_{0}$

4. Penentuan tipe asosiasi dengan menggunakan koefisien asosiasi (V) menurut Krebs (1972) dalam Rondo (2004) yaitu :

$V=\frac{(a d-b c)}{\sqrt{(a+b)(c+d)(a+c)(b+d)}}$

Jika $\mathrm{V}$ bernilai positif, maka kedua spesies berasosiasi positif Jika $\mathrm{V}$ bernilai negative, maka kedua spesies berasosiasi negatif.

Lebar relung (Pianka, 1973 dalam Rondo, 2001)

$$
B=\frac{1}{\sum_{i=1}^{S} P j^{2} S}
$$

Keterangan :

$\mathrm{B}=$ Lebar relung

$\mathrm{Pj}=$ Proporsi suatu organisme pada mikrohabitat tipe-i

$S=$ Jumlah tipe microhabitat 
Tumpah tindih relung (Levin dalam Rondo, 2001)

$a_{i j}=\sum^{n} p_{i h} p_{i j}(B)$

Dimana :

$\mathrm{a}_{\mathrm{ij}}=$ Kealing-likupan/tumpah tindih relung mikrohabitat dari jenis $\mathrm{i}$ terhadap jenis j

$\mathrm{p}_{\mathrm{ih}}, \mathrm{p}_{\mathrm{jh}}=$ Proporsi tiap jenis dalam tipe mikrohabitat ke-h

$\mathrm{B}=$ lebar relung

\section{HASIL DAN PEMBAHASAN}

\section{Komposisi Jenis Mangrove}

Berdasarkan hasil identifikasi jenis mangrove di lokasi penelitian, diperoleh 4 famili dengan 7 jenis mangrove (Tabel 2).

Tabel 2. Komposisi Jenis Mangrove di Pulau Sibu

\begin{tabular}{|c|c|c|c|}
\hline Famili & Jenis Mangrove & Nama Lokal & $\begin{array}{l}\text { Nama } \\
\text { Indonesia }\end{array}$ \\
\hline \multirow[t]{4}{*}{ Rhizophoraceae } & Rhizophora stylosa & Soki-soki & Bakau \\
\hline & $\begin{array}{l}\text { Rhizophora } \\
\text { apiculata }\end{array}$ & Soki-soki & Bakau \\
\hline & $\begin{array}{l}\text { Bruguiera } \\
\text { gymnorrhiza }\end{array}$ & Dau & Tanjang \\
\hline & Ceriops tagal & Ting & Tengar \\
\hline Sonneratiaceae & Sonneratia alba & Posi-posi & Pedada \\
\hline Meliaceae & $\begin{array}{l}\text { Xylocarpus } \\
\text { granatum }\end{array}$ & Kira-kira & Nyirih \\
\hline Myrsinaceae & $\begin{array}{l}\text { Aegiceras } \\
\text { corniculatum }\end{array}$ & $\begin{array}{l}\text { Kacang- } \\
\text { kacangan }\end{array}$ & Rica-rica \\
\hline
\end{tabular}

Famili Rhizophoraceae memiliki jenis lebih banyak yaitu 4 jenis (Rhizophora apiculata, Rhizophora stylosa, Ceriops tagal, Bruguiera gymnorrhiza) sedangkan famili Sonneratiaceae, Meliaceae dan Myrsinaceae masing-masing hanya memiliki 1 jenis. Famili Rhizophoraceae yang ditemukan lebih banyak disebabkan peluang ditemukannya jenis dari famili ini tiap lebih banyak, disamping itu kondisi substrat di lokasi penelitian sangat mendukung pertumbuhan dari famili ini, 
seperti pasir, pasir bercampur patahan karang, lumpur berpasir dan lumpur sebagai media tumbuh bagi famili ini. Hardjowigeno (1986) menyatakan bahwa pengaruh sifat tanah terhadap mangrove antara lain ditunjukkan oleh sebaran genus Rhizophora. Di daerah-daerah dengan tanah berlumpur dalam, Rhizophora mucronata merupakan vegetasi yang dominan, sedangkan daerah-daerah yang berlumpur dangkal didominasi oleh Rhizophora apiculata. Bila tanah banyak mengandung pasir atau karang maka Rhizophora stylosa yang mendominasi.

\section{Komposisi dan Distribusi Gastropoda Pada Berbagai Zonasi Mangrove}

\section{Zona Intertidal Bagian Depan (ZIBD)}

Komposisi jenis gastropoda yang diperoleh pada zona intertidal bagian depan terdiri dari 9 famili, 9 genus dan 15 spesies (Tabel 3).

Tabel 3. Jumlah Famili, Genus dan Spesies Gastropoda pada Zona Intertidal Bagian Depan (ZIBD).

\begin{tabular}{llll}
\hline No. & Famili & Genus & Spesies \\
\hline 1 & Littorinidae & Littorina & Littorina scabra \\
2 & & Littorina undulate \\
3 & Turbinidae & Turbo & Turbo agryrostoma \\
4 & & & Turbo chrysostomus \\
5 & & & Turbo breneus \\
6 & Neritidae & Nerita & Nerita costata \\
7 & & & Nerita planospira \\
8 & Strombidae & Strombus & Strombus luhuanus \\
9 & Potamididae & Cerithidea & Cerithidea cingulate \\
\hline Total & 5 & 5 & 9 \\
\hline
\end{tabular}

Famili yang memliki spesies terbanyak yaitu family Turbo sebanyak 3 spesies (Turbo agryrostoma, Turbo chrysostomus, Turbo brenues). Selanjutnya diikuti oleh famili Nerita dengan 2 spesies (Nerita costata, Nerita planospira), family Littorinidae sebanyak 2 spesies (Littorina scabra, Littorina undulata). Sedangkan famili yang memiliki jumlah spesies sedikit dengan jumlah spesies 1, yaitu masing-masing terdapat pada famili Strombidae (Strombus luhuanus) dan Potamididae (Cerithidea cingulata). 


\section{Zona Intertidal Bagian Tengah (ZIBT)}

Komposisi jenis gastropoda yang diperoleh pada zona intertidal bagian tengah terdiri dari 3 famili, 5 genus dan 6 spesies (Tabel 4). Famili Potamididae memiliki jumlah spesies terbanyak yaitu sebanyak 4 spesies (Telescopium telescopium, Terebralia sulcata, T. palustris, Cerithidea cingulata), sedangkan famili yang memiliki jumlah spesies sedikit masingmasing dengan jumlah spesies 1, yaitu Neritidae (Nerita undata) dan Littorinidae (Littorina scabra).

Tabel 4. Jumlah Famili, Genus dan Spesies Gastrpoda pada Zona Intertidal Bagian Tengah (ZIBT).

\begin{tabular}{llll}
\hline No. & Famili & Genus & Spesies \\
\hline 1 & Neritidae & Nerita & Nerita undata \\
2 & Littorinidae & Littorina & Littorina scabra \\
3 & Potamididae & Telescopium & Telescopium telescopium \\
4 & & Terebralia & Terebralia sulcata \\
5 & & Terebralia & Terebralia palustris \\
6 & & Cerithidea & Cerithidea cingulata \\
\hline Total & 3 & 5 & 6 \\
\hline
\end{tabular}

\section{Zona Intertidal Bagian Belakang (ZIBB)}

Pada zona intertidal bagian belakang diperoleh komposisi terdiri dari 2 famili, 3 genus dan 4 spesies (Tabel 5). famili Potamididae memiliki jumlah spesies terbanyak yaitu sebanyak 3 spesies (Telescopium telescopium, Terebralia sulcata, Terebralia palustris), sedangkan famili yang memiliki jumlah spesies sedikit dengan jumlah spesies 1, yaitu Littorinidae (Littorina scabra).

Tabel 5. Jumlah Famili, Genus dan Spesies Gastropoda pada Zona Intertidal Bagian Belakang (ZIBB).

\begin{tabular}{llll}
\hline No. & Famili & Genus & Spesies \\
\hline 1 & Littorinidae & Littorina & Littorina scabra \\
2 & Potamididae & Telescopium & Telescopium telescopium \\
3 & & Terebralia & Terebralia sulcata \\
\hline
\end{tabular}




\begin{tabular}{llll}
\hline 4 & Terebralia & Terebralia palustris \\
\hline Total 2 & 3 & 4 \\
\hline
\end{tabular}

Zonasi Intertidal Bagian Depan (ZIBD) memiliki komposisi jenis lebih banyak disebakan karena zonasi ini berhadapan langsung dengan lautan sehingga keanekaragaman jenis gastropoda lebih banyak, selain itu disebabkan pula oleh variasi substrat yang heterogen berupa pasir, pasir berlumpur dan pasir bercampur pecahan karang sebagai tempat hidup berbagai fauna hutan mangrove. Sedangkan Zona Intertidal Bagian Belakang (ZIBB) memiliki komposisi jenis gastropoda lebih sedkit, karena zona ini berhubungan langsung dengan daratan yang menyebabkan wilayah ini memiliki substrat yang homogen yaitu berlumpur, sehingga umumnya hanya dihuni oleh famili Potamididae.

Famili Potamididae merupakan famili yang memiliki distribusi lebih luas dibanding dengan famili yang lainnya. Hal ini disebabkan famili ini terdistribusi pada semua zonas dalam hutan mangrove (ZIBD, ZIBT, ZIBB). Namun secara kuantitatif Littorina scabra merupakan spesies yang memiliki jumlah yang melimpah. Jenis ini umumnya ditemukan di substrat dan menempel pada daun, batang serta akar. Abubakar dan Sabar (2007) dalam penelitianya, memperoleh komposisi jenis gastropoda juga lebih banyak pada zona depan dan Potamididae merupakan famili yang memiliki distribusi jenis yang lebih luas yaitu pada ZBD, ZBT dan ZBB dan secara kuantitatif Littorina scabra memiliki jumlah yang melimpah dan umumnya menempel pada daun, batang dan akar mangrove.

Menurut Kartawinata dkk., (1979) bahwa salah satu gastropoda yang mendominasi ekosistem hutan mangrove adalah dari famili Potamididae. Potamididae merupakan penghuni asli hutan mangrove dan mendominasi komunitas hutan mangrove. Gastropoda ini mempunyai adaptasi khusus untuk dapat bertahan di lingkungan hutan mangrove. Budiman (1997) dalam penelitian serupa menemukan bahwa Telescopium telescopium selama periode tidak aktif mencari perlindungan dengan cara membenamkan diri ke dalam lumpur. Arief (2003), menyatakan bahwa kerapatan hutan mangrove dibutuhkan oleh makrobentos. Hal ini berkaitan erat dengan pengaruh terjadinya pasang surut bagi makrobentos yang tidak tahan terhadap salinitas tinggi atau pasang surut. Secara alami, kehidupan makrobentos membutuhkan habitat berlumpur yang telah dihambat oleh perakaran pohon. Apabila terjadi pasang naik, maka makrobentos yang tidak tahan ataupun tahan dengan keadaan tersebut akan segera memanjat perakaran pohon yang ada.

\section{Pola Asosiasi Gastropoda Pada Ekosistem Hutan Mangrove Pulau Sibu}

Analisis asosiasi antar jenis gastropoda dianalisis dengan menggunakan analisis secara kuantitatif, dengan menggunakan koefisien asosiasi (V) menurut Krebs (1972) dalam Rondo (2015). Jenis gastropoda 
yang hidup pada ekosistem hutan mangrove Pulau Sibu ada yang tidak berasosiasi, berasosiasi positif dan berasosiasi negatif (Gambar 1). Pasangan jenis gastropoda yang tidak beraosiasi terdiri dari 42 pasangan yaitu Littorina scabra dengan Littorina undulata. Turbo agryrostomus, Turbo chrysostomus, Turbo breneus, Nerita costata, Nerita planospira, Strombus luhuanus, Cerithiidea cingulata dan Terebralia palustris, selanjutnya pasangan yang tidak berasosiasi yaitu Littorina undulata dengan Turbo chrysostomus, Turbo breneus, Nerita costata, Nerita planospira, Cerithiidea cingulate, Telescopium telescopium, Terebralia sulcata dan Terebralia palustris. Pasangan Turbo agryrostomus dengan Cerithiidea cingulata. Pasangan Turbo chrysostomus dengan Turbo breneus, Nerita costata, Strombus luhuanus dan Telescopium telescopium. Pasangan Turbo chrysostomus dengan Telescopium telescopium. Pasangan Turbo breneus dengan Nerita planospira, Strombus luhuanus, Telescopium telescopium, Terebralia sulcata dan Terebralia palustris. Pasangan Nerita costata dengan Strombus luhuanus dan Telescopium telescopium. Pasangan Nerita planospira dengan Strombus luhuanus, Cerithiidea cingulate, Telescopium telescopium, Terebralia sulcata dan Terebralia palustris. Pasangan Strombus luhuanus dengan Cerithiidea cingulata dan Telescopium telescopium. Pasngan Cerithiidea cingulata dengan Telescopium telescopium, Terebralia sulcata dan Terebralia palustris. Pasangan Telescopium telescopium dengan Terbralia palustris. Pasangan Terebralia sulcata dengan Terebralia palustris. Pasangan gastropoda yang berasosiasi positif terdiri dari 14 pasangan yaitu Pasangan Littrona undulata dengan Turbo agryrostomus dan Strombus luhuanus. Selanjutnya pasangan Turbo agryrostomus dengan Turbo chrysostomu, Turbo breneus, Nerita costata, Nerita planospira dan Strombus luhuanus. Pasangan Turbo chrysostomus dengan Nerita planospira dan Cerithiidea cingulata. Pasangan Turbo breneus dengan Nerita costata dan Cerithiidea cingulata. Pasangan Nerita costata dengan Cerithiidea cingulata. Pasangan Telescopium telescopium dengan Terebralia palustris.

Pasangan gastropoda yang berasosiasi negatif terdiri dari 11 pasangan yaitu Pasangan Littrona scabra dengan Telescopium telescopium dan Terebralia sulcata. Selanjutnya pasangan Turbo agryrostomus dengan Telescopium telescopium, Terebralia sulcata dan Terebralia palustris. Pasangan Turbo chrysostomus dengan Terebralia sulcata dan Terebralia palustris. Pasangan Nerita costata dengan Terbralis sulcata dan Terebralia palustris. Pasangan Telescopium telescopium dengan Terebralia palustris. Semua jenis gastropoda yang tidak berasosiasi memiliki nilai $\chi^{2}$ hit. $<\chi^{2}$ tabel pada taraf $5 \%$, sedngakan gastropoda yang saling berasosiasi karena memiliki nilai $\chi^{2}{ }_{\text {hit. }}>\chi^{2}{ }_{\text {tabel }}$. Sedangkan tipe asosiasi dilihat dari nilai koefisien asosiasi (V) menurut Krebs (1972) dalam Rondo (2015) dimana apabila hasil yang diperoleh positif, maka tipe asosiasi antar jenis gastropoda adalah positif, begitu 
juga sebaliknya apabila hasil yang diperoleh negatif, maka tipe asosiasi antar jenis gastropoda adalah positif.

Spesies gastropoda yang tidak saling berasosiasi menunjukkan bahwa pasangan-pasangan tersebut tidak saling mempengaruhi artinya dapat hidup bersama-sama tetapi membutuhkan sumberdaya yang berbeda-beda. Hal ini dibuktikan juga dari hasil pengambilan data, jenis gastropoda yang ditemukan dalam kuadrat ada yang hidup menempel di batang, akar, daun dan substrat. Seperti salah satu pasangan Nerita costata dengan Strombus luhunus dan Telescopium telescopoum. Jenis Nerita costata ditemukan menempel pada akar dan batang mangrove sedangkan Strombus luhuanus membenamkan diri dalam pasir dan Telescopium telescopium membenamkan diri dalam substrat berlumpur dan lumpur berpasir.

Pasangan jenis gastropoda yang berasosiasi positif menunjukkan bahwa pasangan-pasangan tersebut saling mempengaruhi artinya dapat hidup bersama-sama dan membutuhkan sumberdaya yang sama. Hal ini dibuktikan juga dari hasil pengambilan data, jenis gastropoda yang ditemukan dalam kuadran terdiri dari beberapa jenis dan menempati habitat yang sama seperti pasangan Turbo agryrostomus dengan Turbo chrysostomu, Turbo breneus, Nerita costata, Nerita planospira ditemukan bersama-sama menempati akar, batang dari mangrove. Pasangan jenis gastropoda yang berasosiasi negatif menujukkan bahwa pasanganpasangan tersebut bersifat parasitisme artinya dapat hidup bersama akan tetapi terjadi persaingan dalam menggunakan sumberdaya baik tempat hidup maupun makanan. Seperti pasangan Littrona scabra dengan Telescopium telescopium dan Terebralia sulcata. Dimana Littrorina scabra ditemukan pada habitat lebih luas yaitu saat terjadi surut ditemukan di subtrat dan pada saat pasang memanjat akar, batang dan daun mangrove, sedangkan jenis Telescopium telescopium dan Terebralia sulcata hanya berdiam diri di substrat. Sehingga dapat dikatakan bahwa Littorina scabra memberikan dampak negatif dalam hal pemanfataan habitat maupun kebutuhan makanan bagi kelangsungan hidup Telescopium telescopium dan Terebralia paslustris.

Asosiasi interspesifik merupakan ukuran kemampuan bergabung atau keeratan antara spesies. Asosiasi diukur dengan seberapa sering dua spesies terdapat dalam alokasi (sumberdaya) yang sama (Rondo, 2015). Menurut Odum (1996) bahwa organisme yang berasosiasi positif menunjukkan interaksi yang menguntungkan keduanya tetapi tidak merupakan kewajiban (protocooperasi) dan interaksi menguntungkan keduanya dan merupakan kewajiban (mutualisme) dan asosiasi negatif menunjukkan spesies membutuhkan perbedaan kebutuhan sumberdaya dan dapat terjadi spesies bersaing dalam menggunakan sumberdaya secara eksklusif atau terjadinya persaingan antar spesies. Menurut Hubalek (1982) dalam Ludwig dan Reynolds (1988), bahwa pada umumnya asosiasi antara dua spesies terjadi karena paling sedikit 3 hal yaitu (1) Kedua spesies memilih atau menghindari habitat yang sama atau faktor habitat yang sama, (2) Kedua spesies mempunyai kebutuhan 
lingkungan nir-biotik dan biotik yang umumnya sama dan (3) Satu atau kedua spesies mempunyai afinitas terhadap lainnya, apakah atraksi mutualisme atau repulsi.

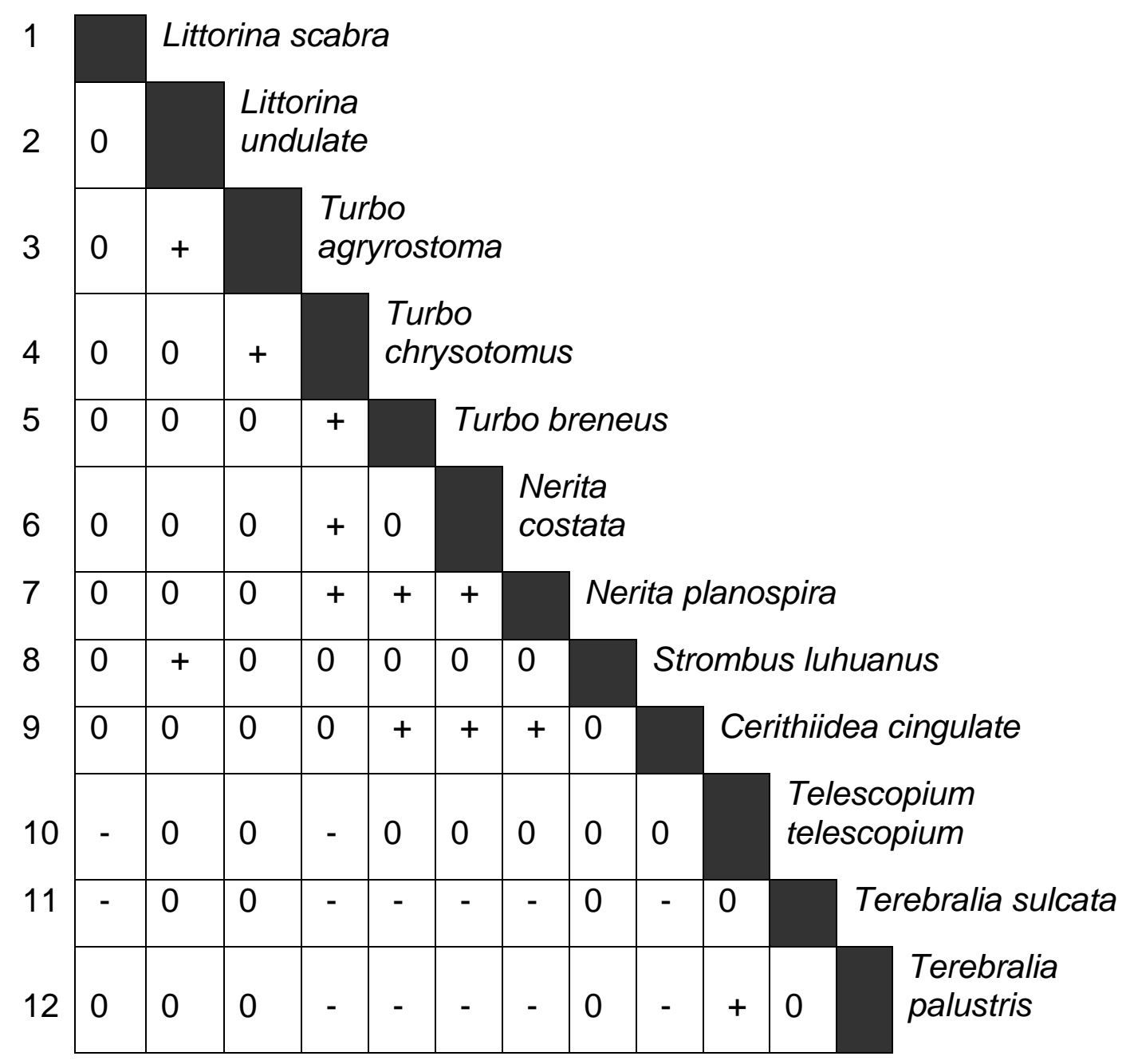

Gambar 2. Matriks asosiasi komunitas gastropoda

\section{Lebar Relung Mikrohabitat Gastropoda Hutan Mangrove}

Hasil penelitian gastropoda yang menghuni hutan mangrove ditemukan pada 7 (tujuh) tipe mikrohabitat yaitu pasir, lumpur, pasir berlumpur, lumpur, lumpur berpasir, akar, batang dan daun (Tabel 6).

Jenis gastropoda yang mempunyai relung habitat terlebar adalah Terebralia sulcata dengan nilai 0,689 , diikuti oleh Littorina sabra, Terebralia palustris, Littorina undulata, Strombus luhuanus, Telescopium telescopium, Nerita costata, Turbo brenues, Cerithiidea cingulata, Turbo agryrostomus dan Nerita planospira. Sedangkan jenis gastropoda yang memiliki relung habitat tersempit adalah Turbo chrysostomus dengan nilai 0,225 . 
Tabel 6. Lebar relung mikrohabitat jenis gatropoda hutan mangrove Pulau Sibu

\begin{tabular}{|c|c|c|c|c|c|c|c|c|c|c|}
\hline \multirow[t]{2}{*}{ No. } & \multirow[t]{2}{*}{ Jenis } & \multicolumn{8}{|c|}{ Mkikrohabitat } & \multirow{2}{*}{$\begin{array}{l}\text { Lebar } \\
\text { Relung } \\
\text { (B) }\end{array}$} \\
\hline & & $P$ & $\mathrm{~L}$ & $P L$ & LP & $A$ & $B$ & $\mathrm{D}$ & Jumlah & \\
\hline 1 & Littorina scabra & & & 7 & 7 & 10 & 21 & 9 & 54 & 0.578 \\
\hline 2 & Littorina undulate & & & & & 8 & 12 & 16 & 36 & 0.399 \\
\hline 3 & $\begin{array}{l}\text { Turbo } \\
\text { agryrostoma }\end{array}$ & & & & & 14 & 8 & & 22 & 0.266 \\
\hline 4 & $\begin{array}{l}\text { Turbo } \\
\text { chrysostomus }\end{array}$ & & & & & 19 & 6 & & 25 & 0.225 \\
\hline 5 & Turbo breneus & & & & & 6 & 4 & & 10 & 0.275 \\
\hline 6 & Nerita costata & & & & & 7 & 5 & & 12 & 0.278 \\
\hline 7 & Nerita planospira & & & & & 5 & 2 & & 7 & 0.241 \\
\hline 8 & $\begin{array}{l}\text { Strombus } \\
\text { luhuanus }\end{array}$ & 3 & 1 & 4 & & & & & 8 & 0.352 \\
\hline 9 & $\begin{array}{l}\text { Cerithidea } \\
\text { cingulata }\end{array}$ & & & & & 18 & 12 & & 30 & 0.275 \\
\hline 10 & $\begin{array}{l}\text { Telescopium } \\
\text { telescopium }\end{array}$ & & 18 & 6 & 9 & & & & 33 & 0.353 \\
\hline 11 & Terebralia sulcate & & 10 & 9 & 7 & 10 & 6 & & 42 & 0.689 \\
\hline 12 & $\begin{array}{l}\text { Terebralia } \\
\text { palustris }\end{array}$ & & 17 & 10 & 6 & 7 & & & 40 & 0.482 \\
\hline Jum & & 7 & 46 & 36 & 25 & 104 & 76 & 25 & 319 & \\
\hline
\end{tabular}

Keterangan : $\mathrm{P}=$ pasir, $\mathrm{L}=$ lumpur, $\mathrm{PL}=$ pasir berlumpur, $\mathrm{LP}=$ lumpur berpasir, $\mathrm{A}=$ akar, $\mathrm{B}=$ batang, $\mathrm{D}=$ daun 
Tabel 7. Tumpah tindih relung mikrohabitat gastropoda hutan mangrove Pulau Sibu

\begin{tabular}{lcccccccccccc}
\hline \multicolumn{1}{c}{ Spesies } & Ls & Lu & $\mathrm{Ta}$ & $\mathrm{Tc}$ & $\mathrm{Tb}$ & $\mathrm{Nc}$ & $\mathrm{Np}$ & $\mathrm{Sl}$ & $\mathrm{Cc}$ & $\mathrm{Tt}$ & $\mathrm{Ts}$ & $\mathrm{Tp}$ \\
\hline $\begin{array}{l}\text { Littorina } \\
\text { scabra }\end{array}$ & & 0.142 & 0.150 & 0.135 & 0.154 & 0.156 & 0.141 & 0.037 & 0.073 & 0.034 & 0.086 & 0.081 \\
$\begin{array}{l}\text { Littorina } \\
\text { undulate }\end{array}$ & 0.098 & & 0.105 & 0.099 & 0.106 & 0.107 & 0.101 & 0.000 & 0.106 & 0.000 & 0.040 & 0.035 \\
$\begin{array}{l}\text { Turbo } \\
\text { agryrostoma }\end{array}$ & 0.069 & 0.070 & & 0.152 & 0.140 & 0.139 & 0.149 & 0.000 & 0.140 & 0.000 & 0.054 & 0.043 \\
$\begin{array}{l}\text { Turbo } \\
\text { chrysostomus }\end{array}$ & 0.053 & 0.056 & 0.128 & & 0.124 & 0.122 & 0.138 & 0.000 & 0.124 & 0.000 & 0.048 & 0.038 \\
$\begin{array}{l}\text { Turbo } \\
\text { breneus }\end{array}$ & 0.073 & 0.073 & 0.145 & 0.152 & & 0.142 & 0.149 & 0.000 & 0.143 & 0.000 & 0.055 & 0.045 \\
$\begin{array}{l}\text { Nerita } \\
\text { costata }\end{array}$ & 0.075 & 0.075 & 0.145 & 0.151 & 0.144 & & 0.149 & 0.000 & 0.144 & 0.000 & 0.055 & 0.045 \\
$\begin{array}{l}\text { Nerita } \\
\text { planospira }\end{array}$ & 0.059 & 0.061 & 0.135 & 0.147 & 0.131 & 0.129 & & 0.000 & 0.131 & 0.000 & 0.051 & 0.040 \\
$\begin{array}{l}\text { Strombus } \\
\text { luhuanus }\end{array}$ & 0.023 & 0.000 & 0.000 & 0.000 & 0.000 & 0.000 & 0.000 & & 0.000 & 0.056 & 0.048 & 0.063 \\
$\begin{array}{l}\text { Cerithidea } \\
\text { cingulate }\end{array}$ & 0.073 & 0.073 & 0.145 & 0.152 & 0.143 & 0.142 & 0.149 & 0.000 & & 0.000 & 0.055 & 0.045 \\
$\begin{array}{l}\text { Telescopium } \\
\text { telescopium }\end{array}$ & 0.021 & 0.000 & 0.000 & 0.000 & 0.000 & 0.000 & 0.000 & 0.056 & 0.000 & & 0.076 & 0.112 \\
$\begin{array}{l}\text { Terebralia } \\
\text { sulcata }\end{array}$ & 0.103 & 0.069 & 0.140 & 0.148 & 0.138 & 0.137 & 0.145 & 0.094 & 0.138 & 0.148 & & 0.167 \\
$\begin{array}{l}\text { Terebralia } \\
\text { palustris }\end{array}$ & 0.067 & 0.042 & 0.079 & 0.081 & 0.078 & 0.078 & 0.080 & 0.086 & 0.078 & 0.153 & 0.117 & \\
\hline
\end{tabular}

Analisis kesaling-lingkupan gastropoda pada hutan mangrove di Pulau Sibu (Tabel 7), terlihat bahwa kesaling-lingkupan relung atau tumpah tindih relung mikrohabitat yang cukup besar dilakukan oleh Terebralia sulcata terhadap Terebralia palustris sebesar 0,167, Littorina scabra terhadap Nerita costata $(0,156)$, Littorina scabra terhadap Turbo breneus. Nilai tumpah tindih relung mikrohabitat yang diperoleh umumnya rendah atau sama dengan nilai yang diperoleh 0,000 . Ini terjadi pada jenis Littorina undulata terhadap Strombus luhunus dam Telescopium telescopium, Turbo agryrostoma terhadap Strombus Iuhuanus dan Telescopium telescopium. Turbo chrysostomus terhadap Strombus luhuanus dan Telescopium telescopium, Turbo breneus terhadap Strombus luhuanus dan Telescopium telescopium, Nerita costata terhadap Strombus luhuanus dan Telescopium telescopium, Nerita planospira terhadap Strombus luhuanus dan Telescopium telescopium, Strombus luhuanus terhadap Cerithiidea cingulata serta Cerithiidea cingulate terhadap Telescopium telescopium.

Lebar relung merupakan luas volume atau volume relung. Hal ini tergantung pada jumlah dimensi lingkungan. Jenis yang mempunyai relung yang lebar menandakan kemampuannya mengeksploitasi sumberdaya yang tersedia (makanan, habitat, waktu dan lain-lain) 
sehingga mempunyai kementakan populasi jenis yang tinggi. Kompetisi intraspesifik akan dialami oleh jenis yang mempunyai relung sempit (Rondo, 2015). Jenis yang mempunyai relung habitat yang lebar menandakan jenis tersebut mempunyai kemampuan mengeksploitasi sumberdaya habitat yang tersedia sehingga mempunyai kementakan populasi jneis yang tinggi. Kompetisi interspesifik akan dialami oleh jenis yang memiliki relung sempit. Jenis Terebralia sulcata memiliki relung habitat terlebar, ini terbukti juga dari hasil pengambilan data ditemukan pada 6 tipe mikrohabitat yaitu lumpur, pasir berlumpur, lumpur, lumpur berpasir, akar dan batang mangrove. Nilai lebar relung selain ditentukan oleh jumlah tipe mikrohabitat yang sanggup ditempati atau dieksploitasi oleh gastropoda, juga ditentukan oleh kesamarataan proporsi kehadiran tiap jenis pada tipe mikrohabitat yang ada.

Sedangkan jenis Turbo chryssostomus memiliki nilai lebar relung sempit atau rendah karena hanya ditemukan pada 2 tipe habitat yaitu akar dan batang mangrove. Pemanfaatan relung habitat yang sempit akan lebih berbahaya terhadap kelangsungan populasinya dari pada jenis yang terdapat pada banyak mikrohabitat. Salah satu tahap untuk mengerti organisasi komunitas adalah mengukur kesaling-lingkupan atau tumpah tindih relung dalam sumberdaya antar spesies-spesies yang berbeda dalam suatu komunitas ataupun antar fase hidup yang berbeda, atau ukuran suatu bagian tubuh dari suatu populasi. Sumberdaya itu dapat berupa makanan, ruang atau mikrohabitat dan waktu (Rondo, 2015).

Hasil analisis diperoleh umumnya nilai kesaling-lingkupan atau tumpah tindih relung mikrohabitat adalah rendah. Hal ini dipengaruhi oleh habitat yang ditempati masing-masing jenis yang berbeda, seperti Littorina scabra menempati habitat pasir berlumpur, lumpur berpasir, akar, batang dan daun mangrove, sementara Strombus luhuanus menempati habitat pasir, lumpur dan pasir berlumpur. Begitu juga Nerita costata terhadap Strombus luhuanus dan Telescopium telescopium, dimana Nerita costata hidup pada akar dan batang mangrove, sementara Strombus luhuanus hidup ada habitat pasir, lumpur dan pasir berlumpur sedangkan Telescopium telescopium hidup pada habitat lumpur, pasir berlumpur, lumpur berpasir. Hal ini menunjukkan bahwa tidak terjadi kompetisi dalam hal ruang ataupun makanan. Nilai kesaling-lingkupan atau tumpah tindih relung yang tinggi terjadi pada Terebralia sulcata terhadap Terebralia palustris, Littorina scabra terhadap Nerita costata, Littorina scabra terhadap Turbo breneus. Ini disebabkan habitat masing-masing jenis umumnya sama sehingga akan terjadi kompetisi dalam pemanfaatan habitat atau makanan. Misalnya Terbralia sulcata dengan Terebralia palustris menempati habitat yang sama yaitu lumpur, pasir berlumpur, lumpur berpasir dan akar mangrove. Selain itu Littrona scabra dengan Telescopium telescopium dan Terebralia sulcata.

Hasil kesaling-lingkupan relung atau tumpah tindih relung mikrohabitat juga berhubungan dengan hasil analisis asosiasi yang diperoleh setiap pasangan gastropoda dimana pasangan yang tidak saling berasosiasi memiliki nilai tumpah tindih relung yang rendah atau tidak 
terjadinya persaingan dalam pemanfaatan sumberdaya, comtoh salah satuanya adalah pasangan Nerita costata dengan Strombus luhunus. Begitu juga sebalikanya pasangan yang memiliki kesaling-lingkupan relung atau tumpah tindih relung mikrohabitat memiliki tipe asosiasi negatif atau terjadi persaingan dalam pemanfaatan sumberdaya, contohnya pasangan Littrona scabra dengan Telescopium telescopium dan Terebralia sulcata memiliki asosiasi negatif. Kesaling-lingkupan relung mikrohabitat dapat menggambarkan kompetisi ruang dan dua jenis yang mempunyai relung yang sama dapat berkoeksistensi kemudian jika anggota populasi makin bertambah, kompetisi antar individu tiap jenis akan bertambah dan lebih kuat dari pada kompetisi antar jenis (Levin, 1968). Kesaling-lingkupan berhubungan erat dengan tipe asosiasi antar jenis. Pasangan jenis yang tidak memiliki asosiasi akan memperoleh nilai tumpah tindih relung yang rendah, sedangkan pasangan yang memiliki asosiasi negatif memiliki nilai kesaling-lingkupan atau tumpah tindh relung yang tinggi atau terjadi persaingan dalam pemanfaatan sumberdaya baik habitat, makanan ataupun waktu (Rondo, 2015).

\section{KESIMPULAN}

Komposisi jenis jenis gastropoda di Pulau Donrotu sebanyak 12 jenis yaitu Littrorina scabra, Littorina undulata, Turbo agryrostoma, Turbo chrysostoma, Turbo breneus, Nerita costata, Nerita planospira, Strombus luhuanus,, Cerithiidea cingulata, Telescopium telescopium, Telebralia sulcata dan Terebralia palustris.Pasangan jenis gastropda yang diperoleh memiliki tipe asosiasi positif sebanyak 14 pasangan, asosiasi negatif sebanyak 11 pasangan dan tidak ada asosiasi sebanyak 42 pasangan. Jenis gastropoda yang mempunyai relung habitat terlebar adalah Terebralia sulcata dan tersempit adalah Turbo chrysostomus.

\section{DAFTAR PUSTAKA}

Abubakar, S dan A. Achmad. 2013. Tumbuhan Air (Panduan Pengajaran). LepKhair. Universitas Khairun. Ternate.

Abubakar, S dan Sabar, M. 2007. Komposisi dan Distribusi Vertikal Gastropoda pada Hutan Mangrove di Kecamatan Oba Selatan Kota Tidore Kepulauan Provinsi Maluku Utara. Penelitian Dosen Muda. Fakultas Perikanan dan IImu Kelautan Universitas Khairun. Ternate.

Arief, A 2003. Hutan Mangrove, Fungsi dan Manfaatnya. Kanisius. Yogyakarta

Bengen, D.G. 2003. Pedoman Teknis Pengenalan dan Pengelolaan Ekosistem Mangrove. Pusat Kajian Sumberdaya Pesisir dan Lautan, Institut Pertanian Bogor. Bogor. 
Budiman, A. 1997. Penelaan Beberapa Gatra Ekologi Moluska Bakau Indonesia. Disertasi. Fakultas Pascasarjana. Universitas Indonesia. Jakarta.

Idris, I. 2004. Pedoman Pengelolaan Ekosistem Mangrove. Direktorat Bina Pesisir. Direktorat Jenderal Pesisir dan Pulau-pulau Kecil. Departemen Kelautan dan Perikanan. Jakarta.

Kartawinata, K.S, Adisoemarmo, S. Soemodiharjo dan I.G.M. Tantar. 1979. Status Pengetahuan Hutan Bakau di Indonesia dalam A. Soemodihardjo dkk. (eds) Prosiding Seminar Ekosistem Hutan Mangrove. Jakarta.

Ludwig, J.A dan J.F. Reynolds. 1988. Statistical Ecology. A Primer on Methods and Computing. A. Willey Interscience Publication New York.

Nybakken, J.W. 1988. Biologi Laut. Suatu Pendekatan Ekologis. PT. Gramedia. Jakarta.

Odum, E.P. 1996. Dasar-dasar Ekologi. Edisi Ketiga. Diterjemahkan oleh Ir. T. Samingan, M.Sc. Gadjah Mada Universitas Press. Yogyakarta.

Rondo, M. 2001. Relung Ekologi. Program Studi IImu Perairan Program Pascasarjana Unsrat. Manado.

Rondo, M. 2015. Metodologi Analisis Ekologi Populasi dan Komunitas Biota Perairan. Program Pascasarjana. Unsrat. Manado.

Saru, A. 2013. Mengungkap Potensi Emas Hijau di Wilayah Pesisir. Penerbit Masagena Press. 